\title{
Meningkatkan Minat Belajar Siswa Melalui Media Visual Pada Materi Upaya Meningkatkan Kualitas Kerja Mata Pelajaran Ekonomi Semester I Kelas XI Ma Negeri Nagekeo Tahun Pelajaran 2018/2019
}

\author{
Ikang Nuria, SE \\ NIP. 197408102007012031
}

\begin{abstract}
Abstrak; Penelitian ini bertujuan untuk mengetahui seberapa besar tingkat minat belajar siswa melalui media Visual pada materi Upaya Meningkatkan Kualitas Kerja ekonomi semester II pada kelas XI MAN Nagekeo. Penelian ini menggunakan analisis data yaitu deskriptif kualitatif, yaitu membandingkan minat belajar sebelum tindakan dengan sesudah tindakan.Berdasarkan nilai hasil belajar siswa didapat dengan rata-rata 78.00, yang berarti telah memenuhi standar KKM yang ditentukan dalam mata pelajaran ekonomiyaitu 65.00. Dengan demikian penelitian ini dapat diterima.
\end{abstract}

Kata Kunci: minat, belajar, media Visual,

\section{PENDAHULUAN}

Pembelajaran ekonomi merupakan salah satu mata pelajaran dalam kurikulum pendidikan yang diajarkan mulai dari tingkat sekolah dasar hingga perguruan tinggi. Ekonomi memuat tentang ilmu ilmu sosial yang pada hakekatnya menganjarkan anak didik agar memiliki rasa sosial tinggi dalam kehidupannya. Melalui pembelajaran ekonomi diharapkan siswa dapat mengetahui keragaman bangsanya, keragaman budayanya, sejarah bangsanya serta keadaan alamnya. Pembelajaran ekonomi dirancang untuk membimbing dan merefleksikan kemampuan siswa dalam kehidupan bermasyarakat yang senantiasa berubah dan berkembang terus menerus.Hal ini merupakan tantangan yang sangat berat mengingat masyarakat secara global selalu mengalami perubahan setiap saat.Oleh karena itu diperlukan suatu pengetahuan yang dapat menunjang pengembangan kreatifitas guru dalam mengajar. Pengembangan kreatifitas dan kemampuan guru ditujukan untuk menghindari permasalahan yang muncul dari diri siswa selama mengikuti pembelajaran ekonomi, karena melalui pembelajaran ekonomi ini diharapkan siswa dapat mengembangkan kemampuan dan sikap yang rasional tentang gejala- gejala sosial serta perkembangan masyarakat Indonesia dan dunia, baik di masa lampau dan masa kini maupun masa yang akan datang.
Dalam pembelajaran ekonomi guru harus dapat menciptakan suasana belajar yang menyenangkan dan penuh antusias bagi siswa. Dalam kegiatan pembelajaran ekonomi yang menyenangkan guru harus didukung oleh alat belajar yang menarik minat belajar sehingga siswa tidak merasa bosan selama mengikuti pembelajaran, sebagaimana dikemukakan oleh Samlawi Fakih (1992) bahwa mata pelajaran ekonomi adalah mata pelajaran yang membosankan, oleh karena itu diperlukan media yang dapat menarik minat siswa untuk belajar. Menyinggung tentang media pembelajaran kita harus menggunakan media pembelajaran tersebut dengan benar dan tepat untuk menunjang proses belajar mengajar yang dilaksanakan, dalam hal ini media yang tepat dapat merangsang siswa untuk lebih mengerti dan memahami materi yang diajarkan. Menurut Gagne (dalam Amidun Rasyad dan Darhim, 1996 1997:97) "media adalah jenis komponen dalam lingkungan siswa yang dapat merangsang untuk belajar“.

Belajar bukan saja melulu penerapan teori semata dan pembelajaran di ruang kelas, tetapi lebih dari itu belajar merupakan cara yang kompleks untuk meningkatkan kualitas sumber daya manusia sebuah bangsa. Oleh sebab itu, ketepatan memilih media pembelajaran merupakan faktor pendukung dalam sukses tidaknya guru mendidik murid menjadi generasi yang dapat diandalkan dan dibanggakan kelak. Oleh karena itu guru 
harus menggunakan media pembelajaran yang tidak saja membuat porses pembelajaran menjadi menarik, tetapi juga memberikan ruang bagi murid untuk berkreasi dan terlibat secara aktif sepanjang proses pembelajaran. Sehingga aspek kognitif ,afektif dan psikomotorik murid pun dapat berkembang maksimal secara bersamaan tanpa mengalami pendistorsian salah satunya. Kenyataan apa yang menjadi harapan dan tujuan di atas belum sepenuhnya terpenuhi. Namun usaha ke arah itu senantiasa dilakukan oleh seluruh elemen pendidikan Hal ini menunjukkan bahwa dengan penggunaan media yang tepat dalam pembelajaran akan menarik minat belajar siswa terutama pada mata pelajaran ekonomi.

Dengan media yang menarik materi pelajaran akan mudah diserap oleh siswa, karena dengan menggunakan media dapat mempermudah pemahaman belajar anak dalam pencapaian tujuan pengajaran. Berdasarkan hasil observasi di MAN NAgekeo, pembelajaran ekonomibelum sesuai diharapkan. Hal ini disebabkan oleh: 1). Kurangnya keterampilan guru dalam memilih media yang tepat dalam pembelajaran, 2). Kurangnya keterampilan guru untuk memanfaatkan media. 3). Minat belajar siswa kurang atau belum sesuai dengan apa yang diharapkan.

Untuk itu diperlukan alat atau media yang dapat menarik minat siswa. Materi tentang upaya meningkatkan kualitas kerja adalah salah satu materi pada pelajaran ekonomi kelas XI MAN semester 1, tetapi ternyata guru dalam melaksanakan pembelajaran kebanyakan masih bersifat konvensional, artinya guru masih mendominasi jalannya pembelajaran dan belum memanfaatkan media pembelajaran secara maksimal sehingga pembelajaran yang dilakukan cenderung kurang menarik siswa. Selain itu guru belum sepenuhnya memanfaatkan alat peraga dalam pembelajaran Ilmu Pengetahuan Sosial. Kebanyakan masih menggunakan alat peraga lembar kerja yang dibeli dari penerbit yang belum sesuai dengan kebutuhan siswa. Untuk mengatasi hal itu perlu diadakan uji coba menggunakan media pembelajaran yang murah dan sederhana yang mudah dipahami siswa yaitu melalui media visual.

Media pembelajaran yang dimaksudkan dalam penelitian ini adalah media yang digunakan untuk menunjang proses belajar mengajar khususnya pada mata pelajaran EKONOMI terutama pada materi tentang upaya meningkatkan kualitas kerja. Adapun media tersebut adalah media visual. Harapan selanjutnya adalah ingin memperbaiki proses pembelajaran dengan memanfaatkan penggunaan alat peraga dan media visual yang murah meriah, mudah didapat . Diharapkan dengan menggunakan media visual lebih mewarnai proses pembelajaran agar pembelajaran lebih bermakna, materi mudah dipamai siswa, bergairah serta bernuansa PAKEM (Aktif, Kreatif, Efektif dan Menyenangkan). Disisi lain siswa pun akhirnya akan lebih akrab dan lebih berminat belajar ekonomi. Dan prestasi belajar siswa meningkat. Berdasarkan uraian di atas maka penulis melaksanakan penelitian tindakan kelas mengenai "Meningkatkan Minat Belajar Siswa Melalui Media Visual pada Upaya meningkatkan kualitas kerjaMata Pelajaran ekonomi Kelas XI MAN Nagekeo Kabupaten Nagekeo".

\section{Masalah Penelitian}

Berdasarkan uraian pada latar
belakang maka permasalahan dapat
diidentifikasi sebagai berikut:
a) Kurangnya keterampilan guru dalam
memilih media yang tepat dalam
pembelajaran

b) Guru belum memanfaatkan ataupun menggunakan media visual

c) Minat belajar siswa kurang atau belum sesuai dengan apa yang diharapkan.

1. PerumusanMasalah

Rumusan masalah dalam penelitian ini adalah "apakah penggunaan media visual dapat meningkatkan minat belajar siswa kelas XI MAN khususnya materi Upaya meningkatkan kualitas kerja pada mata pelajaran ekonomi MAN Nagekeo".

\section{Pemecahan Masalah}

Dalam upaya memecahkan permasalahan tentang rendahnya minat belajar siswa dalam pembelajaran ekonomi, 
proses pembelajaran akan dilakukan dengan menggunakan media visual.

\section{Tujuan Penelitian}

Adapun tujuan yang hendak dicapai dalam penelitian ini adalah:

1. Untuk memperbaiki dan meningkatkan kemampuan guru (peneliti) melalui penggunaan media visual sehingga proses pembelajaran akan lebih baik.

2. Untuk meningkatkan minat belajar siswa dalam pembelajaran ekonomi dengan menggunakan media visual

\section{KAJIAN PUSTAKA \\ Pengertian Minat}

Minat adalah sesuatu yang sangat penting bagi seseorang untuk melakukan suatu aktivitas. Dengan minat orang akan berusaha mencapai tujuannya. Oleh karena itu minat dikatakan sebagai salah satu aspek psikis manusia yang dapat mendorong untuk mencapai tujuan. Ada dua aspek yang dikandung oleh minat antara lain aspek kognitif dan aspek afektif. Aspek kognitif mengandung pengertian bahwa minat selalu didahului oleh pengetahuan, pengetahuan, pemahaman dan konsep yang diperoleh dan dikembangkan dan pengalaman atau hasil interaksi dengan lingkungannya. Aspek afektif menunjukkan pada derajat emosional yang dinyatakan dalam bentuk proses menilai untuk menentukan kegiatan yang disenangi. Jadi, suatu aktivitas bila disertai dengan minat individu yang kuat, maka ia akan mencurahkan perhatiannya dengan baik terhadap aktivitas tersebut. Aspek minat manusia dalam mengikuti pembelajaran ekonomisangat kuat, maka akan merupakan dasar pula untuk menciptakan situasi pembelajaran yang kondusif, yang dapat memenuhi keinginan siswa untuk belajar disertai perhatian yang besar. Sedangkan yang dimaksud dalam penelitian ini adalah bahwa minat untuk mempelajari ekonomimerupakan faktor intern yang mendorong dan mempengaruhi tingkah laku seseorang untuk merasa tertarik dan menunjukkan perhatian terhadap proses pembelajaran ekonomi.

\section{Pengertian Belajar}

Sardiman (2004:2) mengatakan belajar adalah usaha mengubah tingkah laku. Arthur J. Gates dalam Fudyartanto (2002:150) menjelaskan bahawa belajar adalah perubahan tingkah laku melalui pengalaman dan latihan, selanjutnya Hamalik (1994:36) belajar adalah modifikasi atau mempengaruhi kelakuan melalui pengalaman. Menurut pengertian ini belajar adalah merupakan suatu proses kegiatan dan bukan suatu hasil atau tujuan. Belajar bukan saja mengingat, akan tetapi lebih luas daripada itu, yakni mengalami.Hasil belajar bukan suatu penguasaan hasil latihan melainkan perbaikan kelakuan.

\section{Pengertian Minat Belajar}

Minat belajar siswa adalah model bagi siswa untuk melakukan aktivitas belajar dalam usaha mencapai perubahan perilaku. Perubahan perilaku yang dimaksudkan adalah dari perilaku tidak tahu menjadi tahu dan dari perilaku tidak mengetahui menjadi perilaku mengetahui.

Minat pada umumnya sudah terdapat dalam diri seseorang.Akan tetapi biasanya minat juga dapat dipengaruhi oleh sesuatu yang berasal dari luar atau yang sering disebut motivasi atau dorongan.Jika minat yang terdapat dalam diri seseorang sudah cukup kuat, maka dorongan yang berasal dari luar relatif kurang diperlukan.Tetapi sebaliknya, jika seseorang kurang memiliki minat, maka diperlukan dorongan dari luar atau motivasi ekstrinsik yang relatif kuat.

\section{Pengertian Media}

Media secara khusus diartikan sebagai alat komunikasi yang digunakan untuk membawa informasi dari satu sumber kepada penerima. Dikaitkan dengan pembelajaran, media dimaksud sebagai alat komunikasi yang digunakan dalam proses pembelajaran untuk membawa informasi berupa materi ajar dari pengajar kepada peserta didik sehingga peserta didik menjadi lebih tertarik untuk mengikuti kegiatan pembelajaran. Media merupakan wahana penyuluh informasi belajar atau penyalur pesan berupa materi ajar oleh guru kepada siswa menjadi lebih dengan pembelajaran yang dilakukan.Media sengaja dilakukan dengan leluasa, akalanya kita harus membuat sendiri.

Menurut Rahadi Aristi (2004:7) "Media umumnya adalah segala sesuatu 
yuang dapat menyalurkan informasi dari sumber informasi kepada penerima informasi. Istilah media ini sangat popular dalam bidang komunikasi, proses belajar mengajara pada dasarnya juga merupakan proses komunikasi, sehingga media dalam pembelajaran disebut sebagai media pembelajaran.

\section{Media Visual /Gamba}

Media gambar termasuk ke dalam media visual. Sama dengan media lain, yang berfungsi untuk menyalurkan pesan dan penerima sumber ke penerima pesan. Pesan yang akan disampaikan dituangkan ke dalam simbol-simbol komunikasi visual. Supaya proses penyampaian pesan dapat berhasil dan efisien, simbol-simbol tersebut perlu dipahami benar. Secara khusus gambar berfungsi pula untuk menarik perhatian, memperjelas penyajian ide, menghiasi fakta yang mungkin akan cepat dilupakan atau diabaikan bila tidak digrafiskan. Media visual/ gambar berbentuk dua dimensi karena hanya memiliki ukuran panjang dan lebar.Yang termasuk media ganbar adalah gambar, foto, grafik, bagan atau diagram, kartun, komik, poster, peta dan lainlain.Media gambar telah sesuai dengan kemajuan teknologi seperti gambar fotografi. Gambar fotografi bisa diperoleh dari berbagai sumber.gambar yang diperoleh dari berbagai sumber dapat dipergunakan oleh guru secara efektif dalam kegiatan belajar mengajar pada tiap jenjang pendidikan dan berbagai displin ilmu (Sudjana 2000: 78).

1. Kelebihan Media visual/Gambar

a. Sifatnya konkret, gambar lebih realitis menunjukkan masalah dibandingkan dengan media verbal semata.

b. Gambar dapat mengatasi batasan ruang dan waktu. peristiwa-peristiwa yang terjadi di masa lampau tidak kita bisa lihat seperti apa adanya. Gambar amat berguna dalam hal ini.

c. Media gambar dapat mengatasi keterbatasan pengamatan kita.

d. Gambar dapat mamperjelas suatu masalah.

e. Siswa mudah memahaminya.

f. Bisa menampilkan gambar, grafik, atau diagram g. Bisa dipergunakan di dalam kelas, di rumah maupun dalam perjalanan dalam kendaraan.

h. Dapat dipergunakan tidak hanya untuk satu orang.

i. Dapat dipergunakan untuk memberikan umpan balik.

2. Kelemahan Media visual/Gambar

a) Gambar hanya menekankan persepsi indera mata.

b) Gambar benda yang terlalu kompleks kurang efektif untuk kegiatan pembelajaran.

c) Ukuranya sangat terbatas untuk kelompok besar.

d) (Gambar suilit di cari karena sejarah mempelajari masa lalu, dan kejadian masa lalu sulit untuk diabadikan.

e) Tidak semua kejadian masa lalu dapat dibuat gambarnya

3. Pengertian Media Pembelajaran visual/Gambar

Media grafis termasuk kedalam media visual sama dengan media lain, media grafis berfungsi untuk menyalurkan pesan dan penerima sumber kepenerima pesan. Pesan yang akan disampaikan dituangkan kedalam simbol-simbol komunikasi visual. Supaya proses penyampaian pesan dapat berhasil dan efisien, simbol-simbol tersebut perlu dipahami benar. Secara khusus grafis berfungsi pula untuk menarik perhatian, mmperjelas sajian ide, menghiasi fakta yang mungkin akan cepat dilupakan atau diabaikan bila tidak digrafiskan. Pembuatan media grafis sederhana dan mudah jika ditinjau dari segi biaya juga relatif murah. Banyak sekali jenis media gambar. Media gambar merupakan bahasa yang umum yang dapat dimenggerti dan dipahami dimanamana.Media pembelajaran gambar mempunyai beberapa kelebihan (Sadiman, 2003:29-31) yaitu, sifatnya konkrit, gambar dapat mengatasi batasan ruang dan waktu, media gambar dapat mengatasi keterbatasan pengamatan kita, dapat memperjelas suatu masalah, gambar juga dapat digunakan tanpa memerlukan alat khusus.

Namun selain itu gambar mempunyai beberapa kelemahan yaitu hanya menekankan persepsi indera mata, gambar benda yang 
terlalu kompleks kurang efektif untuk kegiatan pembelajaran, ukurannya sangat terbatas untuk kelompok besar. Ada beberapa syarat harus dipenuhi supaya gambar itu baik sebagai media pendidikan setidaknya gambar itu akan cocok dengan tujuan pendidikan. Gambar tersebut harus otentik, sederhana dan ukuran relative serta gambar sebaiknya mengandung gerak atau perbuatan, gambar hendaknya harus dari sudut seni dan sesuai dengan tujuan pembelajaran yang ingin dicapai (Sadiman, 2003:29-31). Dalam upaya untuk pembelajaran atau membelajarkan siswa, peranan dan fungsi media pembelajaran ialah sebagai media komunikasi yang dipakai dalam kegiatan belajar mengajar. Proses belajar mengajar pada hakekatnya adalah proses skomunikasi yaitu proses penyampain pesan melalui saluran atau media tertentu ke penerima pesan. Sumber pesan, saluran atau media dan penerima pesan adalah komponen-komponen proses komunikasi. Pesan yang akan disampaikan adalah isi atau ajaran didikan yang ada dalam kurikulum, sumber pesannya bisa guru, siswa orang lain atau penulis buku dan produser media, salurannya adalah media pendidikan dan penerima pesannya yaitu siswa atau juga guru.

Di dalam pembelajaran sebagai proses komunikasi terdapat kendala-kendala atau gangguan yang mempengaruhinya yang disebut noise. Gangguan-gangguan ini dapat berupa hambatan psikologis seperti: kurangnya minat, rendahnya intelegensi, kualitas seperti: kelelahan, keterbatasan daya indera dan hambatan kultural seperti: kebiasaan serta hambatan yang berasal dari lingkungan. Perbedaan gaya mengajar, minat, intelegensi, keterbatasn daya indera, cacat tubuh atau hambatan jarak geografis, jarak waktu dan lain-lain dapat dibantu dengan pemanfaatan media pendidikan.

Media sebagai salah satu sumber belajar yang dapat membantu guru dan siswa dalam mengatasi hambatan-hambatan yang ada. Oleh karena itu dapat dikatakan bahwa media pembelajaran adalah segala jenis sarana yang dapat di indera yang digunakan dalam proses belajar-mengajar untuk meningkatkan efektivitas dan efisiensi pencapaian tujuan pembelajaran (Sadiman dkk, 2003: 12-13). Dengan demikian media pembelajaran merupakan bagian integral dari proses belajar-mengajar dan bertumpu pada tujuan, materi, pendekatan, metode dan evaluasi pembelajaran ada dua unsur yang terkandung dalam media pembelajaran yaitu: (1) pesan atau bahan pembelajaran yang akan disampaikan, dengan istilah lain yang disebut perangkat lunak (sofware) dan (2) perangkat keras (hardware) yang berfungsi sebagai alat belajar dan alat bantu belajar.Dengan penggunaan media guru dan siswa diharapkan dapat berkomunikasi lebih baik, mantap dan kelas menjadi hidup. Penggunaan media secara kreatif dapat memungkinkan siswa belajar lebih banyak, mencamkan apa yang dipelajarinya dengan baik dan meningkatkan performan siswa sesuai dengan tujuan pembelajaran yang akan dicapai. Macammacam media pembelajaran yang dapat digunakan dalam kegiatan belajar-mengajar dapat dikelompokan sebagai berikut:

1. Bahan publikasi: koran, majalah, buku.

2. Bahan bergambar: gambar, bagan, peta, poster, foto, lukisan, grafik, dan diagram.

3. Bahan pameran: buletin board, papan flanel, papan magnet, papan demonstrasi.

4. Bahan proyeksi: film-film strip, slide trnsparan, OHP.

5. Bahan rekaman audio: tape kaset, VCD.

6. Bahan produksi: kamera, tape recorder.

7. Bahan siaran: pogaram radio, program televisi.

8. Bahan pandan dengar (audio visual) : TV, film bersuara, slaide bersuara.

9. Bahan medel atau benda tiruan, selain masih ada lagi media yang kita kenal antara lain: pertunjukan wayang kulit dan wayang boneka.

4. Pemanfaatan Media visual/Gambar Dalam Pembelajaran ekonomi

Pemanfaatan media gambar sejarah diperlukan strategi yang tepat, hal ini dimaksudkan agar pelajaran tidak terjebak pada sifat monoton dan siswa tidak hanya menonton. Pembelajaran sejarah dengan diawali media gambar akan membawa suasana belajar sesuai dengan tujuan yang diharapkan, kemudian dilanjutkan dengan 
menjelaskan atau menuliskan sejarah yang disajikan dalam gambar.

\section{Pengertian Pendapatan Nasional}

Upaya peningkatan kualitas tenaga kerja tidak hanya menjadi tanggung jawab pemerintah, namun pihak individu dan pihak swasta juga wajib ikut serta untuk meningkatkan kualitas tenaga kerja.Oleh karenanya terdapat 3 Pihak yang wajib ikut dalam Upaya Peningkatan Kualitas Tenaga Kerja. Berikut upaya peningkatan kualitas tenaga kerja yang dapat dilakukan oleh 3 pihak tersebut tersebut:

1. Upaya dari Pihak Individu

2. Upaya Untuk Pihak swasta

3. Upaya Dari Pihak pemerintah.

\section{METODE PENELITIAN}

Penelitian Tindakan kelas ini dilaksanakan di MAN Nagekeo Kabupaten Nagekeo kelas XI MAN semester 1 tahun pelajaran 2018/2019 dengan jumlah siswa 18 orang terdiri 12 siswa laki-laki dan 20 siswa perempuan.

Penelitian ini dilaksanakan selama 2 bulan yaitu dari bulan Januari 2018 sampai dengan pertengahan Maret 2018 waktu ini meliputi kegiatan persiapan sampai penyusunan laporan penelitian.

\section{Prosedur Penelitian}

Dalam pelaksanaannya penelitian ini dilakukan secara kolaboratif dengan guru mata pelajaran ekonomi. Adapun langkahlangkah yang dilakukan untuk tiap siklus pembelajaran dalam prosedur penelitian tindakan kelas ini adalah sebagai berikut:

\section{Siklus I}

1. Tahap Perencanaan

Pada tahap perencanaan ini peneliti melakukan kegiatan sebagai berikut:

a. Mendiskusikan dengan guru mata pelajaran ekonomitentang permasalahan pembelajaran dan tindakan yang direncanakan, serta meminta kesediaan guru mata pelajaran ekonomiuntuk menjadi mitra dalam pelaksanaan tindakan.

b. Menyusun perangkat pembelajaran berupa rencana pembelajaran yang disetting sebagai PTK, bahan pengajaran yang akan diberikan, menyiapkan media pembelajaran pendukung, bahan tugas untuk siswa, kisi- kisi soal, alat evaluasi serta menyusun alat evaluasi bersama guru mitra.

c. Menyusun lembar kerja sisiwa bersama guru.

d. Menyusun lembar observasi aktivitas siswa dan guru bersama guru mitra.

2. Tahap Tindakan

Penelitian ini dilaksanakan secara kolaboratif dengan guru mata pelajaran ekonomi. Adapun kegiatannya sebagai berikut:

\section{Pertemuan pertama}

Dalam pertemuan ini membahas materi tentang mengenal berbagai macam upaya meningkatkan kualitas kerjadengan urutan kegiatan yang dilakukan adalah sebagai berikut:

- Guru memberikan pertanyaan kepada siswa "apakah kalian pernah bertindak untuk mengatasi masalah di sekolah" sebagai prasayarat untuk dapat mengikuti pembahasan materi mengenai upaya meningkatkan kualitas kerja melalui media gambar,

- Guru memberikan motivasi kepada siswa dengan menayangkan gambar lewat LCD mengenai tindakan ekonomi.

- Guru menjelaskan rencana kegiatan dan tujuan pembelajaran.

- Guru memberikan penjelasan mengenai cara menganalisis media gambar

- Guru memberikan soal latihan berupa lembar kerja siswa yang dapat dikerjakan secara individu.

- Guru berkeliling mengawasi dan memberi bimbingan kepada siswa yang kurang mengerti.

- Setelah cukup diberi waktu 30 menit guru bersama siswa membahas soal latihan dengan cara menunjuk siswa untuk memaparkan di depan kelas, dengan bimbingan guru siswa lain mencocokkan hasil kerjanya.

- Selesai membahas latihan- latihan soal, guru menanyakan pada siswa soal- soal manakah yang belum dikuasai ataupun yang sudah dikuasai oleh siswa.

- Guru membimbing siswa untuk membuat rangkuman. 
- Guru memberikan PR kepada siswa untuk dibahas pada pertemuan berikutnya.

\section{Pertemuan kedua}

Kegiatan yang dilakukan dalam pertemuan ini adalah sebagai berikut:

a) Guru membahas PR dan menerangkan soal yang dianggap sulit oleh siswa

b) Guru memberikan soal test pada siklus I dengan waktu 50 menit.

c) Guru mengoreksi hasil kerja siswa dan mempersentasikan hasil tes siklus I

3. Tahap Pengamatan (observasi)

Mengingat dalam penelitian ini dilaksanakan secara kolaboratif dengan guru, maka pada tahap pengamatan (observasi) aktivitas belajar siswa selama kegiatan pembelajaran berlangsung dipantau oleh peneliti dan dibantu oleh salah seorang pengamat dengan menggunakan pedoman lembar observasi aktivitas siswa.

4. Tahap Refleksi

Pada tahap ini data- data yang diperoleh dari siklus I dikumpukan untuk dianalisis dan selanjutnya diadakan refleksi terhadap hasil analisis yang diperoleh, sehingga dapat diketahui ada tidaknya peningkatan aktivitas belajar dan minat belajar siswa sebelum tindakan dan sesudah tindakan.Aktivitas dan minat belajar inilah yang nantinya digunakan sebagai bahan pertimbangan pelaksanaan siklus berikutnya.

\section{Siklus II}

1. Tahap perencanaan

Berdasarkan hasil refleksi pada siklus I baik yang berkaitan dengan sisiwa, guru ataupun perangkat, maka diadakan perencanaan ulang meliputi:

a. Pendekatan, strategi, metode dan media pembelajaran

b. Menciptakan suasana belajar yang lebih melibatkan keaktivan siswa

c. Menyusun struktur pembelajaran yang lebih efektif dan efisien

d. Pengelolaan kelas

e. Perencanaan yang lainnya sama sebagaimana pada perencanaan siklus pertama.

2. Tahap Tindakan

\section{Pertemuan ketiga}

Dalam pertemuan ini membahas materi mengenai motif ekonomi dengan urutan kegiatan yang dilakukan sebagai berikut:

- Guru memberikan pertanyaan kepada siswa "apa motivasi kalian belajar di sekolah "sebagai prasarat untuk dapat mengikuti pembahasan materi mengenai motif ekonomi.

- Guru melaksanakan rencana kegiatan dan tujuan pembelajaran.

- Guru menjelaskan mengenai pengertian motif ekonomi, dan serta macam- macam motif ekonomi.

- Guru memberikan soal latihan berupa lembar kerja siswa yang dapat dikerjakan secara individu dengan media gambar.

- Guru berkeliling mengawasi dan memberi bimbingan kepada siswa yang kurang mengerti.

- Setelah cukup diberi waktu 30 menit guru bersama siswa membahas soal latihan dengan cara menunjuk siswa untuk memaparkan di depan kelas, dengan bimbingan guru siswa lain mencocokkan hasil kerjanya.

- Selesai membahas latihan- latihan soal, guru menanyakan pada siswa soal- soal manakah yang belum dikuasai ataupun yang sudah dikuasai oleh siswa.

- Guru membimbing siswa untuk membuat rangkuman.

- Guru memberikan PR kepada siswa untuk dibahas pada pertemuan berikutnya.

\section{Pertemuan keempat}

- Dalam pertemuan ini membahas materi mengenai simbol- simbol pada peta dengan urutan kegiatan sebagai berikut:

- Guru memberikan pertanyaan kepada siswa" apakah siswa masih mengingat motif produsen dalam memproduksi barang" sebagai prasarat untuk melanjutkan materi minggu lalu.

- Guru memberikan motivasi kepada siswa dengan menunjukkan gambar orang memproduksi barang .

- Guru menjelaskan rencana kegiatan dan tujuan pembelajaran

- Menggunakan media gambar guru memberikan penjelasan mengenai macammacam motif ekonomi, dll 
- Guru memberikan soal latihan siklus II berupa lembar kerja siswa yang dikerjakan secara individu melalui media gambar yang sudah disiapkan.

- Guru berkeliling mengawasi dan memberi bimbingan kepada siswa yang kurang mengerti.

- Setelah cukup diberi waktu 30 menit guru bersama siswa membahas soal latihan dengan cara menunjuk siswa untuk memaparkan di depan kelas, dengan bimbingan guru siswa lain mencocokkan hasil kerjanya.

- Selesai membahas latihan- latihan soal, guru menanyakan pada siswa soal- soal manakah yang belum dikuasai ataupun yang sudah dikuasai oleh siswa.

- Guru mengoreksi hasil kerja siswa dan mempersentasikan hasil tes siklus II

- Guru membimbing siswa untuk membuat rangkuman.

- Guru memberikan motivasi kepada siwa untuk mengulangi penjelasan mengenai materi mengenai macam-macam motif ekonomi dengan menggunakan media gambar.

3. Tahap Pengamatan (observasi)

Observasi dilakukan sebagaimana pada siklus I, yaitu pada tahap pengamatan (observasi), aktivitas siswa selama proses pembelajaran dipantau langsung oleh peneliti dan dibantu oleh salah seorang pengamat dengan menggunakan pedoman lembar observasi aktivitas siswa.

4. Tahap refleksi

Peneliti menganalisis semua tindakan kelas pada siklus II, sebagaimana yang dilakukan pada siklus I. selanjutnya peneliti melakukan refleksi. Apakah dengan media yang digunakan dalam penelitian ini akan meningkatkan minat belajar siswa

\section{Teknik Pengumpulan Data}

Jenis data yang didapat adalah data kuantitatif dan kualitatif. Yaitu sebagai berikut:

1. Data minat siswa diambil dengan cara pemberian angket kepada siswa setelah selesai tiap siklus

2. Data aktivitas belajar siswa dan pelaksanaan pembelajaran diperoleh dari hasil pengamatan kolaborator selama pelaksanaan tindakan tiap siklus dengan menggunakan instrument observasi kegiatan guru dan siswa pada saat KBM

3. Data hasil belajar diambil dengan cara memberikan tes kepada siswa setelah selesai tindakan.

\section{Analisis Data}

Data yang terkumpul dianalisis secara deskriptif kualitatif, yaitu membandingkan minat belajar sebelum tindakan dengan sesudah tindakan.

1. Data tentang minat belajar siswa

Data tentang minat belajar siswa dalam pembelajaran dengan menggunakan media visual dianalisis dengan menggunakan persamaan:\%aspek minat belajar siswa $=$ Jumlah siswa yang minat $\mathrm{x} 100 \%$ Jumlah siswa keseluruhan

2. Data tentang aktivitas belajar siswa

Data tentang aktivitas belajar siswa dengan menggunakan media visual dapatdianalisis dengan menggunakan persamaan: $\%$ aktivitas belajar siswa $=$ Jumlah siswa beraktivitas x 100Jumlah siswa keseluruhan:

3. Data tentang hasil belajar siswa

Data tentang hasil belajar siswa dengan menggunakan media visual dianalisis dengan menggunakan persamaan: $\%$ indikator belajar siswa $=$ Jumlah skor yang diperoleh $\mathrm{x}$ 100. Jumlah Siswa keseluruhan Data tentang hasil belajar dikatakan tuntas apabila sesuai dengan KKM yaitu 65,00

4. Data aktivitas siswa dan minat belajar tercapai apabila secara klasikal $65 \%$ siswa telah melaksanakan

\section{HASIL PENELITIAN}

Deskripsii Hasil Penelitian

Penelitian ini dilaksanakan di kelas XI MAN Nagekeodengan jumlah siswa 18 orang, yang terdiri dari 8 orang siswa laki-laki dan 10 orang siswa perempuan. Menurut pengamatan peneliti secara fisik dan intelegensi bahwa siswa kelas XI MAN Nagekeo memiliki kecakapan yang hampir sama atau rata- rata. Hal ini dapat dilihat pada aktivitas dan minat belajar siswa kelas XI MAN mengenai materi upaya meningkatkan kualitas kerjadi saat melaksanakan observasi 
awal yang menjadi landasan peneliti dalam melakukan tindakan.

a. Observasi Awal

Dari observasi awal yang peneliti lakukan ternyata banyak didapati masalah-masalah serta kelemahan- kelemahan siswa, sehingga siswa tidak tertarik dengan mata pelajaran Ekonomi khususnya materi upaya meningkatkan kualitas kerja. Hal ini disebabkan oleh:

1) Kurangnya keterampilan guru dalam memilih media yang tepat dalam pembelajaran,

2) Guru belum memanfaatkan/menggunakan media gambar.

3) Minat belajar siswa kurang atau belum sesuai dengan apa yang diharapkan. dan masalah yang paling menonjol yaitu dalam melaksanakan pembelajaran kebanyakan masih bersifat konvensional, artinya guru masih mendominasi jalannya pembelajaran dan belum memanfaatkan media pembelajaran secara maksimal sehingga pembelajaran yang dilakukan cenderung kurang menarik bagi siswa. Selain itu guru belum sepenuhnya memanfaatkan alat peraga dalam pembelajaran Ilmu Pengetahuan Sosial. Kebanyakan masih menggunakan lembar kerja yang dibeli. Untuk mengatasi hal itu perlu diadakan uji coba menggunakan media pembelajaran yaitu melalui media visual/gambar.Melihat kondisi tersebut peneliti berkolaborasi dengan guru mata pelajaran ekonomihendak memperbaiki minat belajar siswa ini dengan mempehatikan hal- hal yang harus dibenahi seperti alat atau media yang dapat menarik minat siswa dengan memanfaatkan media visual/gambar dalam proses pembelajaran.

b. Tindakan Siklus I.

Setelah dilakukan observasi awal dan diketahui minat belajar siswa, maka langkah yang selanjutnya adalah dilakukannya tindakan siklus I yang terdiri dari empat tahap. Tahapan- tahapan tersebut adalah sebagai berikut

a) Tahap Perencanaan

Pada tahap perencanaan ini peneliti terlebih dahulu mendiskusikan dengan guru mata pelajaran ekonomitentang permasalahan pembelajaran dan tindakan yang direncanakan, menyusun perangkat pembelajaran berupa rencana pembelajaran yang disetting sebagai PTK, bahan pengajaran yang akan diberikan, menyiapkan media pembelajaran pendukung, bahan tugas untuk siswa, kisi- kisi soal, alat evaluasi serta menyusun alat evaluasi bersama guru mitra, menyusun lembar kerja sisiwa bersama guru, menyusun lembar observasi aktivitas siswa dan guru bersama guru mitra. Dari hasil kesepakatan peneliti bersama kolaborator untuk memanfaatkan media visual/gambar sebagai media yang akan digunakan, pelaksanaan siklus I ini diadakan dua kali pertemuan. Hal ini bertujuan untuk melihat aktivitas siswa dalam meningkatkan minat belajar ekonomiterutama dalam materi mengenal kualitas tenaga kerja. Mengingat betapa kompleksnya materi upaya meningkatkan kualitas kerja jika menggunakan media visual/ gambar yang dapat dilihat secara nyata..

b) Tahap Tindakan

Penelitian ini dilaksanakan secara kolaboratif dengan guru mata pelajaran ekonomi. Adapun kegiatannya sebagai berikut:

Pertemuan Pertama

Dalam pertemuan ini membahas materi tentang mengenai upaya meningkatkan kualitas kerjadengan urutan kegiatan yang dilakukan adalah sebagai berikut:

- Guru memberikan pertanyaan kepada siswa "apakah pernah kalian mengatasi masalah di sekolah" sebagai prasayarat untuk dapat mengikuti pembehasan materi mengenal tindakan ekonomi,

- Guru memberikan motivasi kepada siswa dengan menayangkan media visual/gambar tentang tindakan ekonomi. .

- Guru menjelaskan rencana kegiatan dan tujuan pembelajaran.

- Guru memberikan penjelasan mengenai cara menganalisis gambar .

- Guru memberikan soal latihan berupa lembar kerja siswa yang dapat dikerjakan secara individu. 
- Guru berkeliling mengawasi dan memberi bimbingan kepada siswa yang kurang mengerti.

- Setelah cukup diberi waktu 30 menit guru bersama siswa membahas soal latihan dengan cara menunjuk siswa untuk memaparkan di depan kelas, dengan bimbingan guru siswa lain mencocokkan hasil kerjanya.

- Selesai membahas latihan- latihan soal, guru menanyakan pada siswa soal- soal manakah yang belum dikuasai ataupun yang sudah dikuasai oleh siswa.

- Guru membimbing siswa untuk membuat rangkuman.

- Guru memberikan PR kepada siswa untuk dibahas pada pertemuan berikutnya. Pertemuan kedua

Kegiatan yang dilakukan dalam pertemuan ini adalah sebagai berikut:

a. Guru membahas PR dan menerangkan soal yang dianggap sulit oleh siswa

b. Guru memberikan soal test pada siklus I dengan waktu 10 menit.

c. Guru mengoreksi hasil kerja siswa dan mempersentasikan hasil tes siklus I.

c) Tahap Pengamatan (observasi)

Mengingat dalam penelitian ini dilaksanakan secara kolaboratif dengan guru, maka pada tahap pengamatan (observasi) aktivitas belajar siswa selama kegiatan pembelajaran berlangsung dipantau oleh peneliti dan dibantu oleh salah seorang pengamat dengan menggunakan pedoman lembar observasi aktivitas siswa.Aktivitas siswa dalam pembelajaran ekonomimengenai materi upaya meningkatkan kualitas kerjadengan menggunakan media visual pada siklus I masih kurang, hal ini terlihat dalam beberapa aspek penilaian aktivitas belajar siswa dapat dilihat dalam tabel berikut ini: Tabel siklus 1: Rekapitulasi aktivitas belajar siswa

\begin{tabular}{|c|l|l|l|}
\hline No & \multicolumn{1}{|c|}{ Aspek } & \multicolumn{1}{c|}{$\begin{array}{c}\text { Jumlah } \\
\text { Persentase }(\%)\end{array}$} & \multicolumn{1}{c|}{ ket } \\
\hline 1 & Bertanya & $18.56 \%$ & Belum Tuntas \\
\hline 2 & Jawab & $23,72 \%$ & Tuntas \\
\hline 3 & $\begin{array}{l}\text { Mencari } \\
\text { Sumber Belajar }\end{array}$ & $20.63 \%$ & Belum tuntas \\
\hline 4 & Bekerja sama & $26.81 \%$ & Tuntas \\
\hline
\end{tabular}

Berdasarkan tabel di atas aktivitas siswa dalam aspek bertanya dan mencari sumber belajar perlu ditingkatkan. Sedangkan aspek bekerjasama melampui target yang ditentukan yaitu $65 \%$. Sedangkan hasil angket siswa setelah kegiatan belajar mengajar minat siswa dalam belajar ekonomidengan menggunakan media visual dapat dilihat dalam rekapitulasi tabel berikut ini.Tabel siklus 1, Rekapitulas minat belajar siswa.

\begin{tabular}{|c|c|c|c|}
\hline No & Aspek & $\begin{array}{c}\text { Jumlah } \\
\text { Persentase }(\%)\end{array}$ & ket \\
\hline 1 & $\begin{array}{l}\text { Tidak pernah meninggalkan } \\
\text { pelajaran }\end{array}$ & $23.72 \%$ & Tuntas \\
\hline 2 & Mengerjakan tugas dengan baik & $22.69 \%$ & Tuntas \\
\hline 3 & Focus/konsentrasi dalam belajar & $18.56 \%$ & Tuntas \\
\hline 4 & $\begin{array}{l}\text { Maksimal dalam } \\
\text { tugas mengerjakan } \\
\text { EKONOMI }\end{array}$ & $20.63 \%$ & Tuntas \\
\hline 5 & Tepat waktu mengerjakan tugas & $24.75 \%$ & Tuntas \\
\hline
\end{tabular}

Berdasarkan nilai hasil belajar siswa didapat dengan rata-rata 72.00 , yang berarti telah memenuhi standar KKM yang ditentukan dalam mata pelajaran ekonomiyaitu 65.00

c. Tahap Refleksi

Setelah dilakukannya pelaksanaan maka diadakan refleksi.Kegiatan ini berguna untuk mengetahui ada tidaknya peningkatan aktivitas belajar dan minat belajar siswa sebelum dan sesudah tindakan yang nantinya digunakan sebagai bahan pertimbangan pelaksanaan siklus berikutnya.Berdasarkan hasil refleksi dalam kegiatan pembelajaran secara keseluruhan guru dalam melaksanakan proses pembelajaran berjalan sesuai dengan RPP, tetapi ada yang perlu diperhatikan oleh guru yaitu hendaknya guru memberikan media visual tiap siswa satu gambar agar pembelajaran efektif selain ada yang ditayangkan dalam LCD. Dan memberikan kerja kelompok dalam siklus II.Peneliti menyimpulkan bahwa tindakan yang dilakukan ini belum mencapai indikator kinerja yang sesuai dengan harapan khususnya pada aspek konsentrasi dalam belajar ekonomidan Maksimal dalam mengerjakan tugas mata pelajaran ekonomisehingga dilanjutkan ke siklus berikutnya.

Tindakan Siklus II

1. Tahap perencanaan

Berdasarkan hasil refleksi pada siklus I baik yang berkaitan dengan siswa, guru 
ataupun perangkat, maka diadakan perencanaan ulang meliputi:

a. Pendekatan, strategi, metode dan media pembelajaran

b. Menciptakan suasana belajar yang lebih melibatkan keaktivan siswa

c. Menyusun struktur pembelajaran yang lebih efektif dan efisien

d. Pengelolaan kelas.

e. Perencanaan yang lainnya sama sebagaimana pada perencanaan siklus pertama.

2. Tahap Tindakan

a. Pertemuan ketiga

Dalam pertemuan ini membahas materi mengenai motif ekonomi dengan urutan kegiatan yang dilakukan sebagai berikut:

- Guru memberikan pertanyaan kepada siswa "apa motif kalian belajar" sebagai prasarat untuk dapat mengikuti pembahasan materi mengenai motif ekonomi.

- Guru melaksanakan rencana kegiatan dan tujuan pembelajaran.

- Guru menjelaskan mengenai pengertian motif ekonomi dan macam-macam motif ekonomi.

- Guru memberikan soal latihan berupa lembar kerja siswa yang dapat dikerjakan secara kelompok.

- Guru berkeliling mengawasi dan memberi bimbingan kepada siswa yang kurang mengerti.

- Setelah cukup diberi waktu 30 menit guru bersama siswa membahas soal latihan dengan cara menunjuk kelompok untuk memaparkan di depan kelas, dengan bimbingan guru siswa lain mencocokkan hasil kerjanya.

- Selesai membahas latihan- latihan soal, guru menanyakan pada siswa soal- soal manakah yang belum dikuasai ataupun yang sudah dikuasai oleh siswa.

- Guru membimbing siswa untuk membuat rangkuman.

- Guru memberikan pekerjaan rumah kepada siswa untuk dibahas pada pertemuan berikutnya.

b. Pertemuan keempat
Dalam pertemuan ini membahas materi mengenai simbol- simbol pada peta dengan urutan kegiatan sebagai berikut:

- Guru memberikan pertanyaan kepada siswa" apakah siswa ingat motif produsen memproduksi barang" sebagai prasarat untuk melanjutkan materi minggu lalu.

- Guru memberikan motivasi kepada siswa dengan menunjukkan gambar orang memproduksi barang.

- Guru menjelaskan rencana kegiatan dan tujuan pembelajaran.

- Menggunakan media gambar, guru memberikan penjelasan mengenai macammacam motif ekonomi

- Guru memberikan soal latihan siklus II berupa lembar kerja siswa yang dikerjakan secara kelompok.

- Guru berkeliling mengawasi dan memberi bimbingan kepada siswa yang kurang mengerti.

- Setelah cukup diberi waktu 30 menit guru bersama siswa membahas soal latihan dengan cara menunjuk kelompok untuk memaparkan di depan kelas, dengan bimbingan guru siswa lain mencocokkan hasil kerjanya.

- Selesai membahas latihan- latihan soal, guru menanyakan pada siswa soal- soal manakah yang belum dikuasai ataupun yang sudah dikuasai oleh siswa.

- Guru mengoreksi hasil kerja siswa dan mempersentasikan hasil tes siklus II

- Guru membimbing siswa untuk membuat rangkuman.

- Guru memberikan motivasi kepada siwa untuk mengulangi pelanjelasan mengenai materi mengenal peta dengan menggunakan google earth di rumah.

3. Tahap Pengamatan (observasi)

Observasi dilakukan sebagaimana pada siklus I, yaitu pada tahap pengamatan (observasi), aktivitas siswa selama proses pembelajaran dipantau langsung oleh peneliti dan dibantu oleh salah seorang pengamat dengan menggunakan pedoman lembar observasi aktivitas siswa. Aktivitas siswa dalam pembelajaran ekonomi mengenai materi mengenai motif ekonomi dengan menggunakan media visual pada siklus II 
sudah baik, hal ini terlihat dalam beberapa aspek penilaian aktivitas belajar siswa.

\begin{tabular}{|c|l|l|l|}
\hline No & \multicolumn{1}{|c|}{ Aspek } & \multicolumn{1}{|c|}{$\begin{array}{c}\text { Jumlah } \\
\text { Persentase }(\%)\end{array}$} & \multicolumn{1}{c|}{ Ket } \\
\hline 1 & Bertanya & $24.75 \%$ & Tuntas \\
\hline 2 & Jawab & $28.88 \%$ & Tuntas \\
\hline 3 & $\begin{array}{l}\text { Mencari } \\
\text { Sumber Belajar }\end{array}$ & $25.78 \%$ & Tuntas \\
\hline 4 & Bekerja sama & $30.94 \%$ & Tuntas \\
\hline
\end{tabular}

Berdasarkan tabel di atas aktivitas siswa dalam aspek bertanya dan mencari sumber belajar perlu ditingkatkan. Sedangkan aspek bekerjasama melampui target yang ditentukan yaitu $65 \%$.Sedangkan hasil angket siswa setelah kegiatan belajar mengajar minat siswa dalam belajar ekonomidengan menggunakan media visual.

Berdasarkan nilai hasil belajar siswa didapat dengan rata-rata 78.00 , yang berarti telah memenuhi standar KKM yang ditentukan dalam mata pelajaran ekonomiyaitu 65.00

\section{PEMBAHASAN}

Dari hasil refleksi dan deskrekonomii data yang telah diuraikan tersebut bahwa ternyata dari segi hasil aktivitas belajar, minat belajar dan segi indikator belajar siswa yang diadakan oleh peneliti belum mencapai hasil yang optimal. Hal ini ditunjukkan dengan masih kurangnya minat siswa dalam menggunakan menggunakan media visual terutama pada pembelajaran ekonomi mengenai materi upaya meningkatkan kualitas kerja. Peneliti menyimpulkan bahwa tindakan yang dilakukan ini belum mencapai indikator kinerja yang sesuai dengan harapan dan akan dilanjutkan ke siklus berkutnya. Dari hasil refleksi dan deskrekonomi data yang telah diuraikan tersebut bahwa ternyata dari segi hasil aktivitas belajar, minat belajar dan segi indikator belajar siswa yang diadakan oleh peneliti sudah mencapai hasil yang optimal.Hal ini ditunjukkan dengan nampaknya minat belajar siswa dalam menggunakan media gambar terutama pada pembelajaran ekonomi mengenai materi tindakan ekonomi. Melihat minat belajar siswa kelas XI MAN yang dicapai dari siklus I dan siklus II berarti semakin memperjelas adanya manfaat dari penggunaan media gambar dalam pembelajaran ekonomi terutama materi upaya meningkatkan kualitas kerjaterjadi peningkatan, hal dapat dilihat dari tabel berikut ini;

Tabel V . Rekapitulasi aktivitas belajar siswa

\begin{tabular}{|l|l|l|l|l|}
\hline № & Aspek & Siklus I $(\%)$ & Siklus II $(\%)$ & Peningkatan \\
\hline 1 & Bertanya & $56 \%$ & $75 \%$ & $16 \%$ \\
\hline 2 & Menjawab & $72 \%$ & $88 \%$ & $16 \%$ \\
\hline 3 & mencari sumber belajar & $63 \%$ & $78 \%$ & $13 \%$ \\
\hline 4 & Bekerja sama & $81 \%$ & $94 \%$ & $13 \%$ \\
\hline
\end{tabular}

Sedangkan peningkatan minat belajar ekonomidengan menggunakan media gambar dapat dilihat dalam tabel berikut:

\begin{tabular}{|l|l|l|l|l|}
\hline No & Aspek & Siklus I (\%) & Siklus II (\%) & Peningkatan \\
\hline 1 & $\begin{array}{l}\text { Tidak pernah meninggalkan } \\
\text { pelajaran }\end{array}$ & $72 \%$ & $88 \%$ & $16 \%$ \\
\hline 2 & $\begin{array}{l}\text { Mengerjakan tugas dengan } \\
\text { baik }\end{array}$ & $69 \%$ & $84 \%$ & $15 \%$ \\
\hline 3 & $\begin{array}{l}\text { Focus/konsentrasi dalam } \\
\text { belajarekonomi }\end{array}$ & $56 \%$ & $75 \%$ & $13 \%$ \\
\hline 4 & Bekerja sama & $81 \%$ & $94 \%$ & $13 \%$ \\
\hline
\end{tabular}

Berdasarkan deskrekonomii yang dijelaskan pada pembahasan tersebut, maka jelaslah bahwa media gambar telah berhasil meningkatkan aktivitas belajar siswa sesuai dengan indikator yang diharapkan yakni jika aktivitas belajar siswa selama proses pembelajaran mencapai $65 \%$ dan jika minat belajar siswa yang dikenai tindakan memperoleh daya serap $65 \%$ ke atas selama proses pembelajaran.

Dengan demikian, maka hipotesis tindakan yang berbunyi "Jika Dalam Pembelajaran ekonomi Khususnya Materi Peta Diajarkan Dengan Menggunakan Media Gambar, Maka Minat Belajar Siswa Kelas XI MAN Nagekeo akan meningkat dan dapat Diterima".

\section{Kesimpulan}

Dengan pelaksanaan pembelajaran ekonomipada materi peta dengan pemanfaatan media gambar yang sesuai dengan prosedur yang direncanakan mampu meningkatkan aktivitas belajar siswa, minat belajar siswa dan hasil belajar siswa kelas XI MANNagekeo dari rerata 72,00 pada siklus pertama sedangkan rerata siklus kedua rerata menjadi 78,00 kelas XI MAN Nagekeo.

\section{SARAN}

Berdasarkan kesimpulan yang telah diperoleh maka dapat disampaikan beberapa saran sebagai berikut :

1. Kepada kepala sekolah 
a.Lebih memperhatikan sarana dan prasarana yang menunjang kegiatan pembelajaran baik di kelas maupun di luar kelas.

b.Hendaknya lebih menekankan pada guru untuk menggunakan media pembelajaran yang tepat, mudah dan murah untuk kelancaran proses belajar mengajar sehingga dapat meningkatkan mutu pendidikan.

2. Kepada Guru

a.Diharapkan dalam suatu pembelajaran dapat menggunakan media yang tepat demi mendukung kelancaran pembelajara

b.Diharapkan kepada guru agar selalu menggunakan media gambar pada pembelajaran ekonomitentang materi upaya meningkatkan kualitas kerjaagar siswa lebih berminat belajar ekonomi.

\section{DAFTAR PUSTAKA}

Arif Sardiman. 2004. Interaksi dan Motivasi Belajar Mengajar. Jakarta Raja Grasindo Persada

Arthur J. Gates dalam Fudyartanto http://www.find-docs.com/aspek-aspekminat-belajar-pada-siswa.html(27-1-

2011) (Diakses tanggal 10 Januari 2019)

Crow, L.D., dan Crow, A. 1982. Psikologi Pendidikan, penerj. Kasijan Z,. Surabaya: PT Bina Ilmu

Dailer dalam Sumartono. 1983. Modifikasi Kegiatan Belajar Mengajar. Bandung Tarsito

Dimiyati dan Mudjiono. 1999. Belajar Dan Pembelajaran. Jakarta. Rineka Cipta

Hamalik.2004. Kurikulum dan Pembelajaran. PT. Bumi Aksara

Mohamad Arbin Samsudin, 2005. Psikologi Pendidikan. Jakarta PT.Rosdakarya

Purbakawaca dalam Nurkancana, 1987. Kurikulum dan Pembelajaran. Jakarta Rineka Cipta

Rahadi Aristo. Media Pembelajaran. Direktorat Jendral Pendidikan Dasar. Jakarta

Uno.Dkk. 2004. Model Pembelajaran. Nurul Jannah Gorontalo

Usman Basirudin. 2002. Metode Pembelajaran. Ciputat Press. Jakarta 